\title{
Anxiety about reactor accident subsides
}

LAST week's panic in Western Europe and elsewhere about the explosion and subsequent graphite fire at the Soviet nuclear plant north of Kiev was in retreat earlier this week, as the scanty data available outside the Soviet Union were pieced together. While it is plain that the accident at Chernobyl on 26 April was the world's most serious nuclear accident so far, there is no reason to dispute the Soviet statement that only two people at the plant were killed, perhaps a consequence of the initial explosion. The longer-term consequences, including cases of radiation sickness which will become apparent in the next few weeks, and excess cancer deaths, which will be delayed by decades, cannot yet be estimated.

Part of the basis for this reassuring conclusion is the examination of members of the party of British students from Kiev and Minsk, who returned via Moscow last week. Although some of the party's clothing was contaminated with local fallout, ingestion of airborne radioactivity was apparently not sufficient to cause risk of thyroid cancer. An account of the fallout over Poland during the past week, given by a group of Polish experts in Vienna, has led the Polish authorities to the conclusion that there is "no significant risk to the health of any person".

Other estimates of the total quantity of radioactivity released from the Chernobyl reactor have been derived from computer models normally used in the assessment of the risks of nuclear accidents. These suggest that the release from the plant may have been upwards of two orders of magnitude greater than from the British accident at Windscale in 1957, previously the worst nuclear accident on record.

The Swedish measurements, the first clue (on 28 April) to the accident at Chernobyl, suggest that airborne activity over Scandinavia peaked on Tuesday last week at about 10 to 20 times the normal level, mostly because of iodine-131 and caesium-137.

Fallout in the neighbourhood of the plant has been much more serious. Close on 50,000 people have been evacuated from a $30 \mathrm{~km}$ radius. Soviet spokesmen visiting the West have spoken of radiation doses at the plant which were initially 200 roentgens an hour, falling to 100 roentgens an hour after a week. In this light, the Soviet statement that 200 people were hospitalized (of whom a quarter were discharged) probably refers to those showing symptoms of radiation sickness.

The cause of the accident remains a matter for speculation. The most common suggestion is that a leak in the steamraising water circuit which contains the fuel elements and interpenetrates the 1,000-tonne graphite moderator would have produced water gas (carbon monoxide and hydrogen), which might then have caused the explosion that destroyed the roof of the reactor building. It is not known whether Soviet statements that "human error" was responsible for the accident refers to the execution of an improper operation or to an inadequate response to warning signals.

Another possibility is that the accident arose during an operation to anneal the graphite moderator in the reactor to remove structural defects accumulated during prolonged neutron irradiation, and which entails heating the graphite above the normal operating temperature for more than a day.

Although the Chernobyl accident may have been less serious than first reports in Western Europe suggested, most Western governments have been indignant that so little information has been available from Soviet sources to suggest how governments elsewhere might best deal with the fallout from the plant. More detailed information about conditions at Chernobyl began appearing only earlier this week. On Tuesday Pravda carried a long article describing conditions around the reactor site.

Perhaps more significantly, an apparently painful interview last Wednesday between the director-general of the International Atomic Energy Agency, Hans Blix, and the Soviet envoy in Vienna had led, by Sunday, to an invitation for Blix to visit Moscow. He left the same day, accompanied by Maurice Rosen, the agency director of nuclear safety.

According to a spokesman of the agency on Tuesday this week, the intention is that the visitors will have full access to what information there is available in Moscow, although it is not known whether the party will be able to visit the reactor site. Blix's companions may stay in the Soviet Union for several days.

Within the Soviet Union, a commission of enquiry under a deputy prime minister is said to be hard at work on an investigation of the causes of the accident and into its aftermath. On the assumption that the reactor building can itself eventually be made safe, the most haunting problem will be that of managing the health of the population in the neighbourhood of the accident over the next three decades.
Soviet nuclear reactors

\section{Ambitious plans with red tape}

UNTIL 26 April, the Soviet Union had a nuclear generating capacity of $28 \mathrm{GW}, 11$ per cent of total electricity output, but the new five-year plan (1986-90) includes the commissioning of a further $41 \mathrm{GW}$ of nuclear capacity.

Guarded comments by Soviet officials last week suggest that there will be no change in these plans, even though it has for the first time been admitted that the use of nuclear power, even for peaceful purposes, cannot be totally safe. Previously, the Soviet line has been that incidents such as Three Mile Island were the result of corner-cutting by capitalists bent on profit.

Soviet plans specifically suppose the construction of nuclear stations close to major cities. Although, a few years ago, a leading party monthly carried an article suggesting that nuclear stations should be confined to the remoter areas of Siberia, they are now considered so safe that they can serve as thermal generators for city district heating systems, but with a green belt of $1-3 \mathrm{~km}$ radius around each station, which would be used for recreational purposes and allotments.

Current plans call for several such "atomic-thermal-power" stations to be commissioned during the next five years, including Gor'kii, Voronezh, Odessa and Minsk, while the construction of several more is to be started. If the Chernobyl accident has any effect on Soviet nuclear policy, it is in this sphere that it is most likely to be felt.

The resiting of at most 10 or 12 power stations (and the quiet dropping of the district heating part of the programme) would be far less difficult, both logistically and politically, than a total reversal of Soviet commitment to nuclear energy. There is likely, too, to be an increased impetus to the fusion energy research programme, which for years has been formally hailed as the ultimate solution to Soviet energy problems.

The Chernobyl station had four RBMK reactors with a fifth under construction. This is a light-water-cooled uraniumgraphite channel system, with zirconium alloy fuel cans. As a number of commentators have noted, this type of design has been rejected in Western countries as unsafe, and the presence of the earliest example of this type near Leningrad has, during the past few days, evoked considerable concern in Finland.

The Soviet designers seem to have relied on the regular ultrasonic and acoustic monitoring of the metal coolant loops, which, it was claimed in the technical journal Atomnaya Energiya (50, 